\title{
Contagious Diseases and its Consequences in the Late Qajar Period Mashhad (1892-1921)
}

\author{
Jalil Ghassabi Gazkouh; PhD', Hadi Vakili, PhD'; Seyyed Mehrdad Rezaeian, MA²; Seyyed Alireza Golshani, PhD ${ }^{13}$; Alireza Salehi, MD, \\ $\mathrm{MPH}, \mathrm{PhD}^{3^{*}}$ \\ 'Department of History, Dr. Ali Shariati Faculty of Letters and Humanities, Ferdowsi University of Mashhad, Mashhad, Iran \\ ${ }^{2}$ Department of Food Hygiene and Aquatics, Faculty of Veterinary Medicine, Ferdowsi University of Mashhad, Mashhad, Iran \\ ${ }^{3}$ Research Center for Traditional Medicine and History of Medicine, Shiraz University of Medical Sciences, Shiraz, Iran
}

\begin{abstract}
One of the historical periods of Iran that can be studied for contagious diseases and how they spread, is the late Qajar period. The city of Mashhad, after Tehran and Tabriz, had a special place among Russian and English governments in the Qajar period as one of the significant religious, political and economic centers in Iran due to Imam Reza's holy shrine, a large population and great geographical scale. The central governments' incompetence in preventing the outbreak of contagious diseases and lack of essential amenities, caused many lives to be lost all over Iran and especially Mashhad during the Qajar period. Hence, the neighbor governments such as Russia, ordered for quarantines to be set up at the borders and dispatched doctors to stop diseases' from reaching Russian lands. However, these attempts did not prevent the deaths of people in the border areas, especially in Mashhad, from diseases such as cholera, plague, smallpox, typhus, flu and other diseases. In this study, we investigate and explain the subjects: disease outbreaks, the problem of commerce, quarantine and its outcomes at the end of Qajar period, between the years 1892 and 1921 AD in Mashhad, with the help of historical and documentary sources using an analytical and medical historiography method. Keywords: Ancient, Disease Outbreaks, Quarantine, Iran

Cite this article as: T. Contagious diseases and its consequences in the Late Qajar period Mashhad (1892-1921). Arch Iran Med. 2020;23(6):414-421. doi: 10.34172/aim.2020.37.
\end{abstract}

Received: October 15, 2019, Accepted: December 21, 2019, ePublished: June 1, 2020

\section{Introduction}

Medicine went through fundamental changes during the Qajar period. Hence, we can divide it into two periods in terms of Iranian medicine and its changes: The first one beginning from the dawn of the Qajar reign and continuing for a few years after Naser al-Din Shah's reign. In this period, Iranian medicine is practically the old style of medicine practiced by Ibn Sina and Razi (Galen) with of course minor changes employed over time. ${ }^{1}$ The second period began in the midst of Naser al-Din Shah's reign and continued until the Persian Constitutional Revolution during which the modern medicine gradually entered the country and replaced traditional medicine; in other words, Galen's and Ibn Sina's medicine was replaced by Harvey's and Pasteur's or modern European medicine. In the second period, scientific methods of treatment and other matters regarding modern medicine began emerging in Iran by sending students to foreign countries, the establishment of Dar ul-Funun and health institutions, European doctors arriving in Iran and approval of the laws of medicine in the 2nd National Consultative Assembly (November 15, 1909 to December 25, 1911). ${ }^{1}$ In this study, we discuss this second period with a focus on Mashhad and also disease outbreak and the matter of trade, quarantine and its consequences between the years 1897 and 1921 .

Mashhad, as the capital of Khorasan province, was one of the major cities in northeast Iran. Due to its geopolitical, economic, cultural and pilgrimage status in the late Qajar period, it was a point of interest to the great powers of the region such as Russia, Britain, Afghanistan and India. From the early Qajar period, during Fath-Ali Shah Qajar's reign (1797-1834) and after the treaty of Turkmenchay in February 21, 1828, the Russian empire became interested in eastern Iran; during the reign of Naser al-Din Shah Qajar (1848-1896), the Russian Empire caused Turkmenistan, Transoxiana and Chorasmia's definitive separation from Iran. ${ }^{2}$ The circumstances in India were one of the main incentives that attracted Russia's interest in the eastern regions of Iran and particularly Mashhad. After that, the city attracted more attention from Russia due to economic and political reasons. ${ }^{3}$

Following this, the British government developed a strong presence in Mashhad and Khorasan to prevent Russia from infiltrating India. Mashhad was of particular importance to the governments of Afghanistan and India for political, pilgrimage and trade relations. Nevertheless, the presence of Russian and British forces in Mashhad posed economic, political and security problems to the 
people. Purchase, hoarding and export of raw materials such as wheat and barley from Khorasan by Russian and British forces caused famine and consequently disease. Iran's undeveloped state in the field of medicine, shortage of experienced doctors, medical supplies and drugs needed in times of outbreak of contagious diseases in most cities, including Mashhad, had no result other than human catastrophes which will be discussed below.

\section{Disease Outbreak and the Matter of Commerce (Trade)} Mashhad had bad weather conditions. According to the available reports, Mashhad was not temperate in any of the four seasons. Winters were extremely cold and the temperature would rise or fall every few days during spring and fall. Due to temperature change, rhinitis and malaria were very common in the winter; and summer had terrible weather because of all the filth and sludge in the streets, pathways and corridors. ${ }^{4}$ In 1892 , there was an outbreak of cholera in the Herat region. Despite the quarantine in Bakharz and Taybad, sanitation officers could not prevent the spread of the disease to Mashhad. With this spread in May 15, 1892, some 20000 people lost their lives in and around Mashhad. ${ }^{5}$ Haj Abulqasim Malek al-Tojjar, a prominent Iranian merchant, writes about the outbreak and business slack in Mashhad on January 20, 1892, "It has been one or two months since cholera spread around Mashhad. People were in fear. The Mashhadis fled. Trading was in a standstill state and no merchant was found who could do a trade worth of 100 dinars." Malek al-Tojjar also mentioned, "Nobody thinks about doing business and trading in the city; there is no money here." He states that he stayed in the land for the purpose of commerce, earning 10 tomans of money. Survivors from the disease were so busy with mourning and prayer that had no time for trade. ${ }^{6}$ Cholera in other countries and lands beyond the borders also caused many problems for Iranian businessmen. ${ }^{6}$

Cholera was considered as one of the epidemic and dangerous diseases in the Qajar period; it once again spread through Mashhad and Khorasan from July 11 to September 3, 1904. ${ }^{5}$ This lethal disease, also known as "Maraze-Mout" or "Margamargi" (meaning death disease), would usually affect people who lacked basic healthcare supplies, economic welfare and social security benefits. ${ }^{7}$ From an economic viewpoint, cholera decreased the active population and caused a reduction in agricultural and industrial products. Also, with the outbreak of cholera, trading caravans did not travel and transferring merchandise stopped altogether. This fatal disease spread through Iran every year or once every two years and weakened the thread of life and paralyzed the society. ${ }^{7}$ Europeans first came to know cholera from India in the east in 1817 and called it "Cholera", the Indian cholera or the Asian cholera. The Qajar rulers in Iran did not take proper actions in times of outbreak. Most of them would flee and by hiding the truth, deceive the people and leave them in the midst of chaos. The agents of the government would not inform other countries about the outbreak out of fear of road closures. They even opposed to establishing a quarantine that required different expenses. ${ }^{7}$

Furthermore, during the cholera outbreak, quarantine stations were built between cities in Iran. For instance, on August 10,1918, the general consul of England in Mashhad, William George Grey, reports on the status of cholera epidemic in Mashhad, "It has been three days since cholera has appeared in Mashhad in such way that half of the infected people die." The English consul believed that because too many travelers and traders travel from Mashhad to Kerman and back, whenever cholera spreads through Mashhad, it reaches Kerman within a few days. In order to stop the contagion from Khorasan to Kerman, quarantine stations must be set up in Darband Ravar and Bafgh districts, on the way from Khorasan and Yazd to Kerman. ${ }^{8}$ In times of an outbreak in a state, all the roads leading to that state were blocked by the order of the government and all the trading caravans and travelers had no choice but to travel through the routes specified by the government. This issue had some negative effects on commerce. Trading caravans had to travel only along the assigned routes and were sometimes forced to travel very long distances. Crossing these long roads led to lengthier transportation of merchandise for the caravans and more expensive products for the consumers. ${ }^{8}$

Marvin L. Entner considered the outbreak of cholera in Iran and Russia from 1832 to 1835 , as a main reason for the decline in trade between Russia and Iran [Mashhad]. ${ }^{9}$ On July 12, 1892, the cholera disease that was epidemic in Afghanistan reached Khorasan and Mashhad through Herat and killed many people in Mashhad in one month. Afterwards, the disease found its way to Tehran through Shahroud. About this event, Joannes Fauvrier (18421895) writes, "No action was taken by the government to 'confront and prevent contagion' of the disease which had spread across Khorasan, ${ }^{10}$ and due to the cholera outbreak in Iran, trading suffered an awful shock, business and businessmen were put in distress all over the country ${ }^{11}$ (Figure 1).

A disease outbreak in Russia in October 1892 took the lives of approximately 300000 people. This matter had negative effects on trading caravan's traffic to Mashhad. ${ }^{12}$ At the beginning of March 1897, the Russian government deployed many soldiers, Cossacks and doctors to its borders with Iran under the pretext of protecting the border from the plague in Mumbai. No cases of plague were detected in Balochistan, Afghanistan and Iran. However, the Russian government sent 150 Cossack troops to Iran and stationed them on the Iranian-Afghan border from Zulfiqar to the south of Hashtadan and sent many Russian doctors to Kariz and Torbat Heydariyeh and also banned all travel between Iran and Afghanistan or Balochistan. All the roads 


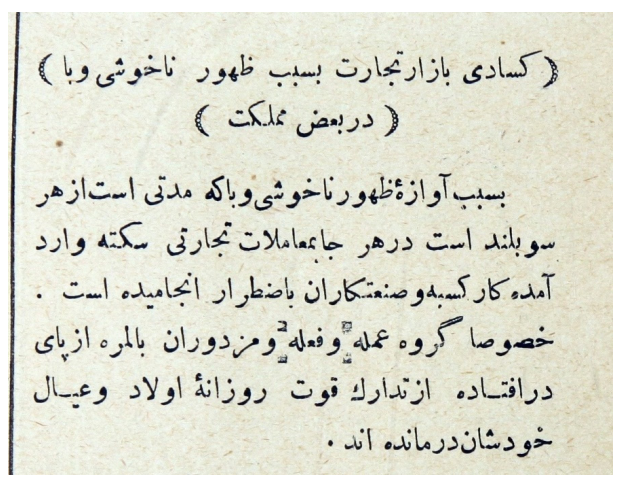

Figure 1. Akhtar (Magazine) ${ }^{11}$; the Effect of Cholera Outbreak on the Decline in Iranian Trade.

were closed and trade between the two countries became stagnant. ${ }^{13}$ Moreover, in October of 1910, cholera had widely spread across the northern regions of Khorasan; it was suspected that the disease had reached Khorasan and Mashhad from Russia. ${ }^{14}$ This situation rose great discontent in Mashhad. The people of this city had solid business relations with Herat for many years, providing essential supplies for their lives through this route. The closure of this road led to a significant increase in the cost of these supplies. Strict regulations were put in place. Packages shipped from Quetta in Pakistan, Kandahar and Herat to Mashhad were seized, every single envelope and package was opened and sanitized and then permitted to cross the border. As a result of closing the borders due to the plague epidemic, the British trade with Mashhad through India was aborted for a while and Afghanistan's trading relations with Iran gave its place to Russia. In consequence, countless merchants in Mashhad suffered from losses and bankruptcy and business was put in disarray. ${ }^{13}$

One of Mashhad's main routes for trading with foreign land was the Mashhad-Herat route. On May 3, 1903, given the severity of the cholera outbreak in India (Mumbai, 6571 infected) and (Karachi, 568 infected), people entering Khorasan from India and Afghanistan were checked more thoroughly. The cholera disease which spread through Mashhad in 1893 was not from Balochistan; it had actually reached Mashhad from the Kandahar-HeratKahriz (Kariz) route. Again in 1903, another cholera epidemic was brought to Mashhad through the KabulKandahar-Herat route. Since merchants and pilgrims' travel was mostly carried out through the roads mentioned above rather than the Balochistan route, quarantine stations were necessary on the caravans' way. Despite all these precautions, the disease eventually reached Mashhad through Herat. In order to stop the disease from reaching Russia, the Russian government closed its borders with Khorasan. Although the borders were blocked for less than a month, trade in Khorasan suffered a loss of 1 million tomans (equal to 150 million US dollars). Entrusting the quarantine stations on the way of Khorasan to Afghanistan to Russian doctors was another adopted precaution. ${ }^{15}$
The cholera epidemic of 1904 in Iran and Afghanistan had reached these two countries from India and took people's lives everywhere. ${ }^{16}$ When the infection started in India in 1907, given that Khorasan was in a state of health and security, immediately after finding out about the epidemic in India and discussing the fact that the disease had contaminated some parts of Afghanistan closer to India, in order to prevent the disease from reaching Khorasan, Doctor Mir Abd al-Rahim Khan and a health guard, Mohammad Hossein Khan of Khorasan's Eastern border agency, began to set up quarantines. ${ }^{17}$ Korpatkin, Ashgabat's ruler in Turkmenistan, wanted to close all Iranian-Russian borders and stop the traffic. However, because of the remarks made by the Russian embassy, he confined his actions to setting up quarantines to prevent the disease from reaching Russia. ${ }^{18}$ However, closing the borders by Ashgabat's ruler could also stagnate the business relations between Iran and Russia which was very damaging to Khorasani and Mashhadi merchants. Iran's government was forced to prohibit pilgrims from entering Mashhad in order to prevent the outbreak of contagious diseases. The Russian embassy considered this action a factor in the process of reducing public infections and therefore, had asked Iran's government to interdict pilgrim's entry to Mashhad before the disease reaches Russia and is completely terminated in Mashhad. ${ }^{19}$ The Ministry of Foreign Affairs ordered the Ministry of Interior that anyone possessing a health permit from quarantine doctors will have the right to enter Iranian territory. ${ }^{20}$

In 1904, cholera caused many deaths in Mashhad. For instance, Mirza Mohammad Kazem, pen named Malek o-Sho'arā Sabouri (1853-1904) had died of cholera. ${ }^{21}$ The spread of cholera had so many fatalities between July 1 and August 24, 1905 that the cadavers were piled up in front of the morgue like firewood. ${ }^{22}$ Again on November 9, 1916, cholera outbreaks have been reported in Mashhad. ${ }^{23}$ Although doctors have not mentioned the intensity of the outbreak in this period, consecutive reports to the Health Preservation Consul show that the situation in Mashhad deteriorated and on February 26, 1917 the death toll had risen from 2 or 3 a day and even 7 had been reported. ${ }^{23} \mathrm{On}$ April 5, 1917 there was an increase in the number of people infected with cholera. Due to the panic of the residents in Mashhad and the fact that they concealed their disease, the Khorasan Health Preservation Commission could not properly identify the number of patients and the deceased for every disease. ${ }^{23}$ On April 28, 1917, doctors in Mashhad reported that, "Cholera has broken out in Mashhad since August 16, 1917; although not very acute in Mashhad itself, cholera is relatively severe in some surrounding areas and especially on the roads; two parasangs from Mashhad, on the way to Tehran, it has been reported to be more severe". ${ }^{18}$

In May 1921, a cholera outbreak had occurred in Ashgabat, infecting 4 or 5 people per day. In order to 
prevent the epidemic transmission to Iran, a quarantine zone was set up in Sarhadat. Thus, those who aimed to gain entry into Iran needed a medical certificate of anticholera vaccination; otherwise they would not be let into the country. There was also a quarantine zone set up in Sarhadat to prevent the spread of cholera from Tashkent. ${ }^{24}$ In addition, according to existing documents, in March 1921, there had been measles and typhus outbreaks reported in Turkistan. Thus, the Health Preservation Council ordered the Khorasan State Health Commission to distribute protective and medical pamphlets among the public in order to prevent the outbreak. ${ }^{24,25}$

There was also a smallpox epidemic in Mashhad in 1907. During this time, some of the charities, including the Sa'adat Charity Foundation (May 12, 1907), which included a group of doctors and businessmen of Mashad, did an important job in outbreak prevention. Dr. FathAli Khan (member of the Sa'adat Charity Foundation) alongside two philanthropist doctors inoculated children free of charge. Dr. Fath-Ali Khan's clinic was in ChaharBagh alley, Mashhad. Mu'tamid-al-Hokama, a Dar-alShifa (hospital) doctor, had an office in the hospital and Ziya-al-Atebba's clinic was located in Imam Reza's shrine, Mashhad. All these doctors inoculated children in their clinics. ${ }^{26}$

Smallpox became the cause of public concern once again in December 1920. In order to eradicate the smallpox disease in Mashad, smallpox vaccine material was sent from Tehran and doctors in Mashad began inoculating children. Sufficient amounts of vaccine material were sent to other provinces by the Vaccination Commission. ${ }^{27}$

According to existing documents, On October 3, 1903 a veterinarian of Ottoman nationality, Mohammad Ra'uf Beyg, reported a case of cholera, even though the foreign minister, Mushir al-Dawlah, expressed doubts in a telegraph to the Minister of Science, Nayer al-Dawlah, about the truth of said report. ${ }^{15}$ In addition, since April 5, the cholera outbreak claimed 9 lives, 6 of whom were city residents and 3 lived in the nearby Toroq village. ${ }^{23}$ The Head of State Health Preservation Commission, Dr. Hazeq al-Dawlah, sent a report of actions taken towards the prevention of further cholera outbreaks to the Government House of Health Preservation. ${ }^{28}$ On September 29, 1917 , cholera was declining in Mashhad thanks to the report sent to Health Preservation Council, in such a manner that between the 18th and 25th of September, only 11 out of 53 contagious disease-related deaths were associated with cholera. ${ }^{23}$ As stated by the Mashhad moratorium records office on September 16, 1917, 58 deaths were reported including 11 cholera victims. ${ }^{23}$

According to a telegraph from Mashhad to the Health Preservation Council in September 1917, cholera started spreading in the lower areas of the city, and the disease had apparently contaminated most neighborhoods in the city. The contagion in Sarab neighborhood was quite critical and in spite of hiding the disease, 168 people had lost their lives to cholera ${ }^{23}$ (Figure 2).

In the daily reports of Mashhad, written mostly by doctor Hazeq al-Dawlah to the foreign ministry, the number of the deceased is specified precisely. For instance, on September 22, 1917, about 23 people died of cholera. On September 13,1917, according to the examinations of doctors from the state Health Preservation Commission in Mashhad, 9 deaths were related to cholera and 60 were due to other diseases. On September 6, 1917, there were 10 cholera-related deaths out of a total of 27 . In another report from September 5, 1917, a total of 31 people passed away in Mashhad, 11 of whom were victims of cholera. On September 101917 , a total of 12 out of 26 deaths were caused by cholera and as specified by Chenaran city's (50 km northwest of Mashhad) Health and Safety officer, cholera was sighted up to 10 parasangs (equal to $26.4 \mathrm{~km}$ ) from Ashgabat and Quchan. On the night of April 10, 23 deaths were reported; 8 of them had died of cholera. On September 9, out of 26 deaths, 12 were cholera-related ${ }^{28}$ (Figure 3 and 4).

Also, Zahir al-Din Khan, a commission doctor from Khorasan state, mentions in his report that on September 11,1917 , up to 65 people in Mashhad died of cholera but the morgue only announced 18 cholera deaths. ${ }^{28}$ Due to lack of medical equipment in Mashhad, it was not possible to find a cure for cholera. ${ }^{28}$ The Health Preservation Commission members in Mashhad included Doctor Hofmann, Doctor Zahir al-Din Khan, Doctor Hazeq alDawlah, Malek al-Hokama and Buqrat al-Hokama. ${ }^{28}$ In addition, in his report of Mashhad on August 26, 1917, Dr. Scott writes that 7 or 8 out of the 25 deceased people had cholera. Dr. Hofmann also mentions that about 20

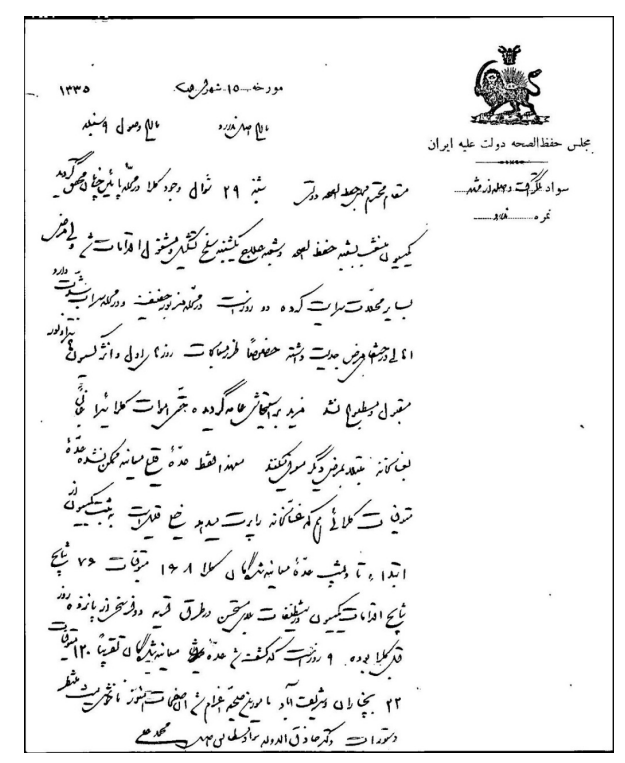

Figure 2. Iranian Foreign Ministry Documents Archive ${ }^{28} ; \mathrm{A}$ Report on the Spread of Cholera Over Numerous Districts of Mashhad from the Mashhad Health Preservation Commission to the Iran Health Preservation Council on September 2, 1917. 


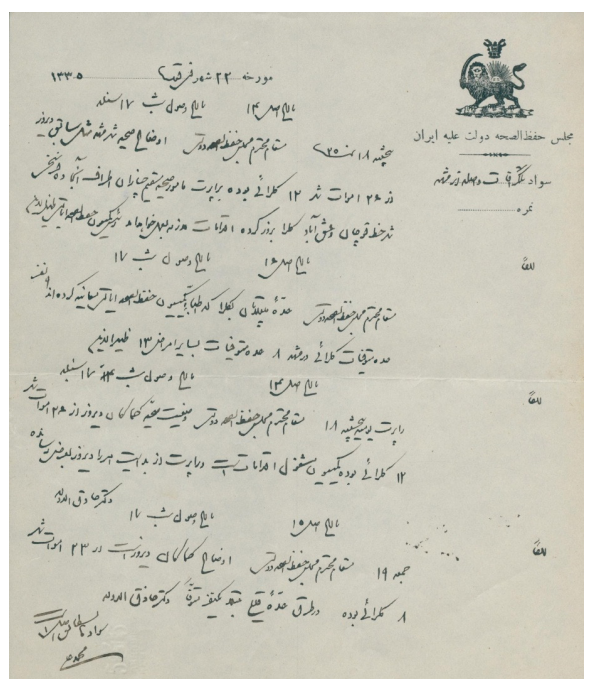

Figure 3. Iranian Foreign Ministry Documents Archive ${ }^{28}$; A Report on the Disease's State in Mashhad and the Spread of Cholera to the Outskirts of the City from the Mashhad Health Preservation Commission to the Iran Health Preservation Council on September 9, 1917.

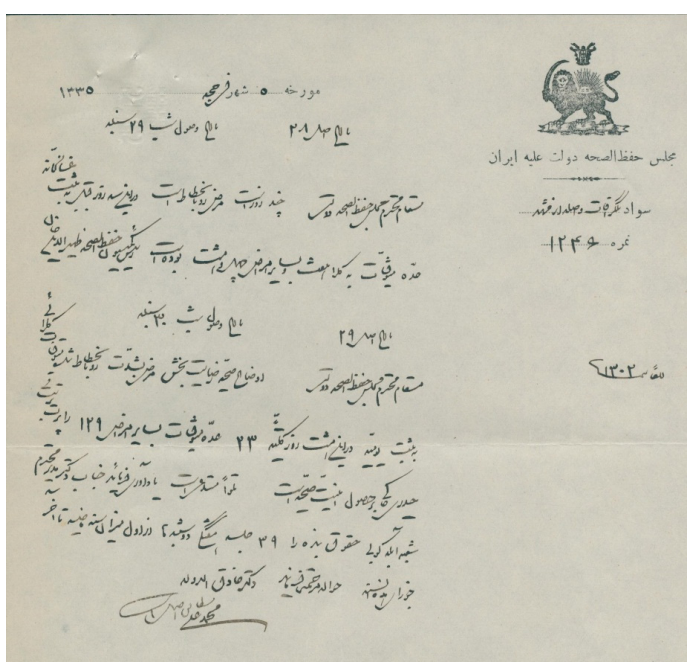

Figure 4. Iranian Foreign Ministry Documents Archive ${ }^{28}$; Mashhad Health Preservation Commission's Report on Control Over the Disease and a Decline in Mortality Rate.

infected people lived in the southern areas of Mashhad. ${ }^{23}$ On August 25, Dr. Scott talks about 75 people suffering from cholera. ${ }^{23}$ Dr. Grey counts 6 cholera-infected people all of whom died. Also, on August 30, 13 cases were identified, 7 of whom had died. On August 31, there were 5 or 6 infected people in Mashhad who had died of cholera. ${ }^{23}$ Hazeq al-Dawlah, a member of the Mashhad Health Preservation Commission, writes in a telegraph to the Health Preservation Council on September 15, 1917, "Smallpox infections have been detected since a few days ago. We, the two vaccinators in Mashhad (Buqrat alHokama and Hazeq al-Dawlah), acquired some vaccines from Dr. Hofmann." And they began vaccination. Nevertheless, Hazeq al-Dawlah complained about not receiving his monthly salary. ${ }^{28}$

Moreover, some other diseases were spreading over Mashhad, some of which were unknown to medical community of that time. For instance, "there was a suspicious illness called 'Disease X' that affected a number of people in Mashhad; but the neither the disease itself nor its cure were discovered. ${ }^{27}$ Also in September 1908, in Ghale'e tokhm marz, $12.5 \mathrm{~km}$ from Mashhad, a disease similar to typhoid fever affected 21 people, 17 of whom died and 4 recuperated. Malak al-Hokama, a Health Preservative and the governor of Khorasan, dispatched Dr. Fath-Ali Khan and an English doctor to the area for research and disease diagnosis. ${ }^{29}$ After the foundation of Sehat pharmacy, the use of foreign medicines became prevalent. Sayed Hossein Tabatabaei, a pharmacist and the manager of Sehat pharmacy, purchased some of the medicines required for the hospital from Russia. He mentioned clearance problems for medicine in Ashgabat (Capital of Turkmenistan) in a letter to Haj Zahir alIslam, head custodian of Astan Quds. On April 22, 1917, he wrote, "In the course of my travel to Russia for the purpose of purchasing medicine for Razavi hospital, I acquired 8 boxes of medicine which were held back in Ashgabat by officers." Because of a collapse in the hospital system, he (Sayed Hossein Tabatabaei) asked Haj Zahir al-Islam to get a permission from the Russian Consul so the transportation of medicine would not be stopped during the war. On April 25, 1917, Zahir al-Islam sent a letter about the eight aforementioned boxes to the Russian Consul and asked them to lift transportation limitations. World War I (January 28, 1914- November 11, 1918) restricted the use of trading routes with Russia and also caused difficulties in providing and transporting medicine from Russia to Mashhad. ${ }^{30}$ Police reports in Mashhad showed the number of deaths caused by contagious disease on March 24, 1920.. ${ }^{31}$

Nevertheless, in June 1920, doctors from Mashhad's municipality took measures to diagnose and treat diseases. They also published a statement in the press, announcing the patient mortality rate ${ }^{32}$ (Figure 5). Disease outbreaks had a direct impact on the traffic of business caravans. When a disease spread through an area, specific places were chosen along the path for the setup of quarantine stations as a solution for stopping the contagion from affecting other areas. Therefore, the traffic of business caravans was slowed down.

One of the diseases that caused many deaths and affected almost one-third of the Iranian population, was the Spanish flu in $1918 .{ }^{33}$ One of the ways through which this disease entered Mashhad was through Ashgabat in Russia; the disease spread over to the west from the Tehran route and to the southern cities of Birjand, Sistan and Yazd. According to Professor Willem Floor, out of a population of 100000 in Mashhad, about 70000 became ill and about 3500 people died, ${ }^{34}$ although it seems exaggerated. 


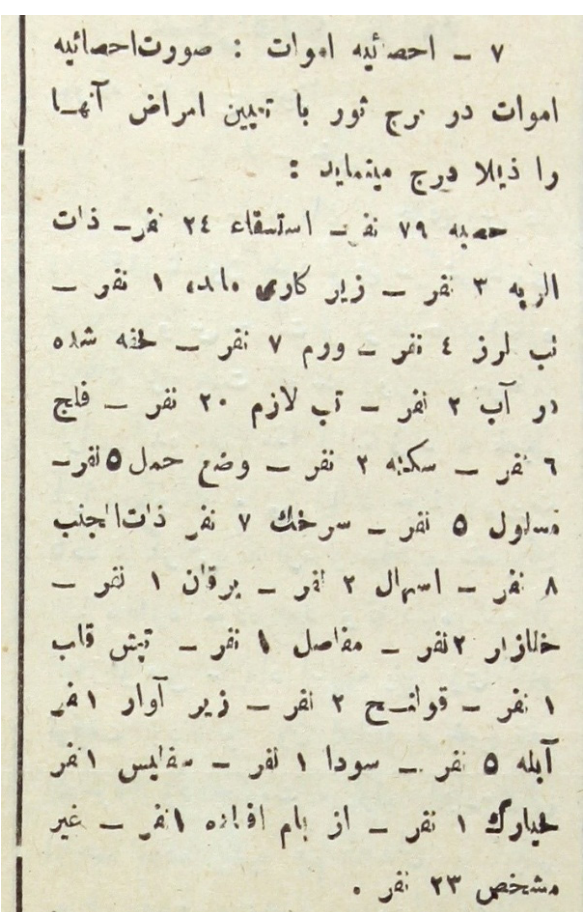

Figure 5. Ra'd (newspaper) 32; A report Printed in Ra'd Newspaper on the Mortality Rate and Cause of Death in Mashhad, June 1920.

\section{Quarantine}

At the beginning of Mozaffar ad-Din Shah's reign (18961907), cholera had spread through India. Therefore, the Russian government set up quarantine stations in Sistan and near Afghanistan's border and also sent a number of Russian doctors to examine the travelers who were traveling from India to Khorasan so they could be stopped from entering Khorasan in case they were carrying cholera. ${ }^{35}$ In March 1897, they also set up a quarantine zone in Khavaf. The cargoes transported from Yazd, Kerman, Herat and Bandar Abbas to Mashhad were held back in this center. Based on the book of Health Preservation, a 15-day-quarantine was established. The cargo carried by camels that had been on the road from Bandar Abbas for 4 months, was abandoned in the desert of Khavaf for 32 days. ${ }^{36}$ In March 1901, due to the outbreak of whooping cough and quarantine zones on the way from Afghanistan to Iran, fewer Afghan convoys travelled the area. This reduction in traffic led to the deficiency and inflation in the prices of oil and rice in Khorasan and Mashhad. ${ }^{37}$ The government sent agents to the contaminated areas in order to prevent the disease from spreading. In July 1901, Mirza Kazem was appointed as the agent-doctor of quarantine in Mashhad $^{37}$ (Table 1).

In December 1905, a plague outbreak happened around Khorasan and Sistan. The disease first appeared in Sistan. Later on, it was reported to have reached Khorasan's border. Following this outbreak in Sistan, the Russian Consul in Mashhad announced that until the disease is wiped out, all trading actions will be ceased ${ }^{20}$ (Table 2).
Table 1. Ra'd Newspaper ${ }^{37}$; A report from Mashhad municipality on the death rate of contagious diseases March 24, 1920

\begin{tabular}{lc}
\hline Disease & Number of Dead in Mashhad \\
\hline Typhoid fever & 66 \\
Polydipsia & 28 \\
Smallpox & 15 \\
Gout & 45 \\
Strange and unknown disease & 68 \\
Total & 224 \\
\hline
\end{tabular}

Table 2. Ra'd Newspaper ${ }^{39}$; A report from Mashhad police on the number of deaths, the common diseases and their mortality rates June 1920

\begin{tabular}{|lc|}
\hline Disease & Number of Dead in Mashhad \\
\hline Typhoid fever & 79 \\
\hline Polydipsia & 24 \\
\hline Smallpox & 5 \\
\hline Pneumonia & 3 \\
\hline Accident with Wagon & 1 \\
\hline Edema & 7 \\
\hline Fever & 4 \\
\hline Drowned & 2 \\
\hline Hectic Fever & 20 \\
\hline Paralysis & 6 \\
\hline Apoplexy & 2 \\
\hline Childbirth & 5 \\
\hline Tuberculosis & 5 \\
\hline Unknown & 23 \\
\hline Measles & 7 \\
\hline Pleurisy & 8 \\
\hline Diarrhea & 2 \\
\hline Jaundice & 1 \\
\hline Palpitations & 1 \\
\hline Spasm & 1 \\
\hline Scrofula & 1 \\
\hline Joint Pain & 1 \\
\hline Beneath the Rubble & 1 \\
\hline Syphilis & 1 \\
\hline Suda Disease & 1 \\
\hline Bubonic Plague & 1 \\
\hline Falling From Roof & 1 \\
\hline Total & 1 \\
\hline
\end{tabular}

In the second half of January 1906, an assembly was held to set up quarantines along the borders for containing the disease. Afterwards, a telegraph was sent to Paris, requesting for 500 bottles of anti-plague infection serum to Iran. ${ }^{38}$ The French government's medical assistances continued during the late Qajar period through its Embassy. The French Embassy provided various types of medicine for Iranian patients through the Health Preservation Consul in July $1920^{39}$ (Figure 6).

According to Floor, in 1920, three leper colonies existed in Iran. One of which was located near Mashhad. The British government in India handled the lepers' treatment costs and their separation from the general population. ${ }^{40}$

\section{Dar Al Shifa and Mashhad Hospitals}

Between the years 1897 and 1921, several hospitals were 


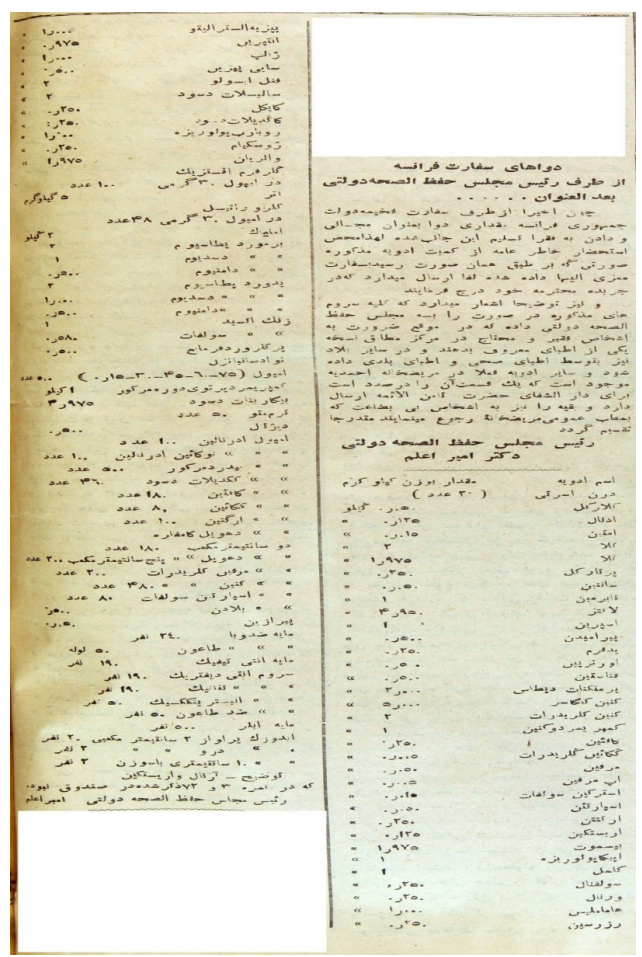

Figure 6. Ra'd (Newspaper) ${ }^{39}$; A report Printed in Ra'd Newspaper. The list of medicines given for free to the Iranian government by the French Embassy in June, 1920.

active in Mashhad, one of which was known as Dar Al Shifa, founded during the reign of King Tahmasp I (15241576) and was a few centuries old. ${ }^{41}$ In 1880 , it was once again well-equipped with the help of Astan Quds Razavi's financial resources. But with the outbreak of World War 1 (28 July 1914 - 11 November 1918), the hospital was completely abandoned and shut down. But in 1919, on a pilgrimage to Mashhad, the head of Health Preservation Council made an effort to reopen two old hospitals and took measures for public health in the Khorasan province. ${ }^{40}$

As stated by Willem Floor, a number of hospitals in Mashhad were managed and funded by the Russian and British governments and the Presbyterian Mission Agency. ${ }^{40}$

\section{Conclusion}

Analyzing Mashhad's society terms of trade, medicine, quarantine and outbreaks of different diseases in the late Qajar period, between the years 1897 and 1921, is only possible with the help of local history resources, newspapers and the documents archive of the Ministry of Foreign Affairs due to Mashhad's poor medical historiography. Mashhad's underdevelopment in the field of medicine in the late Qajar period alongside a high mortality rate, the spread of known and unknown diseases, actions taken by the Iranian government and Imperial Russia and Britain's intervention in treatment and prevention affairs, can be of great assistance to medical history and science researchers who study Mashhad's local medical history and outbreaks of contagious diseases in that short and specific historical period at the end of the Qajar period.

\section{Authors' Contribution}

MF: Idea and design of the research. MF and SAG: Collecting of data. MF: Drafting and finalizing the manuscript.

\section{Conflict of Interest Disclosures}

The authors have no conflicts of interest.

\section{Ethical Statement}

The Research Center for Traditional Medicine \& History of Medicine, Shiraz University of Medical Sciences approved the study. The author(s) received financial support for the Research Center for Traditional Medicine and History of Medicine, Shiraz University of Medical Sciences authorship, and/or publication of this article.

\section{Acknowledgements}

We thank the Research Center for Traditional Medicine \& History of Medicine, Shiraz University of Medical Sciences.

\section{References}

1. Alijani M. A review of the history of medicine in Iran, with emphasis on the Qajar period. Journal of Medicine and Cultivation. 2012;21(1):57-64.

2. Curzon GN. Persia and the Persian Cuestion. 1st ed. London Longmans, Green, and Co. 1892;194.

3. Sir Percy S. A History of Persia. 2nd ed. London: Macmillan \& Co. Ltd; 1921:351.

4. Tehrani MA. Social and Political Observations and the Analysis of the History of the Constitutional Revolution. Introduction Katouzian N (in Farsi). Tehran: Publication Joint Stock Company; 2000: 63.

5. Reyazi-Heravi MY. Eyn al-Vaghayye. Edited by Fekrat MA (in Farsi). Tehran: Publications and Education of the Islamic Revolution; 1993: 105-159.

6. Nategh H. Businessmen in Trading with Imperial Bank of Persia and Tobacco Protest (in Farsi). Tehran: Toos Publication; 1994:239-241.

7. Nategh H. Cholera disaster and government disaster (in Farsi). Tehran: Gostareh Press; 1979:11-25.

8. Rostaii M. The history of medicine in Iran (from the Qajar era to the end of the Reza Shah era) by the narrative of the documents (in Farsi). Tehran: National Library Archives of IR;2003:365-6.

9. Entner ML. Russo-persian commerical relations, 1828-1914. University of Florida Press; 1965.

10. Fauvrier J. Three years at the court of Iran. Farsi translation by Ashtiani A.E, Shahidi H. Tehran: Donyayeh Ketab; 1983:379.

11. Akhtar (magazine). 1893:20(11):167.

12. Ala-al-Mulk M. Historical-Political Reports of Ala-al-Mulk. Trans. by Safayi E. Tehran: Abad Publishing Group. 1983:130.

13. Yate CE. Khurasan and Sistan. W. Blackwood; 1900. Trans. by Roshani G, Rahbari M. Tehran: Yazdan Publications; 1986: 278.

14. Afshar E. Roznameh Khaterat Eyn al-Saltaneh (in Farsi). 4th ed. Tehran: Asatir publications;1998: 3202.

15. Ministry of Foreign Affairs of the Islamic Republic of Iran. Archive. 1903: 19-6/28, 1-1/20,21,22.

16. Mostofi A. Sharh-e Zendegi Man (Tarikh-e Ejtema'i va Edari-e Doreh-ye Qajar) . 2nd ed. (in Farsi). Tehran: Zavar Publications; 1981;58.

17. Iran (magazine). 1897;906(1):3.

18. Ministry of Foreign Affairs of the Islamic Republic of Iran. Archive. 1907: 10-05/29, 28-53/23.

19. Ministry of Foreign Affairs of the Islamic Republic of Iran. Archive. 1904: 13-10/071.

20. Ministry of Foreign Affairs of the Islamic Republic of Iran. Archive. 1906: 19-8/3, 10-14/58.

21. Bamdad M. Dictionary of national bibliography of Iran 1700 -1960 (in Farsi). 5th ed. Tehran: Zavar Publications; 1992:259. 
22. Adib-Heravi MH. Hadigh al-Razaveyeh (History of Mashhad). (in Farsi). Mashhad: Khorasan Printing Company; 1948: 388.

23. Ministry of Foreign Affairs of the Islamic Republic of Iran. Archive. 1916; 28-53/37, 28-53/33-34, 28-53/57, 25-1/547, 85-53/14, 28-53/70, 25-1/534, 25-1/444, 25-1/445, 25-1/448.

24. Ministry of Foreign Affairs of the Islamic Republic of Iran. Archive. 1921; 23-43/3-4, 32-9/47-50.

25. Azizi MH, Bahadori M, Azizi F. An Overview of Epidemic Typhus in the World and Iran during the 19th and 20th Centuries. Arch Iran Med. 2016;19(10):747-50.

26. Khorshid (newspaper). 1907;1(10):4 .

27. Ra'd (newspaper). 1920;11(152):3.

28. Ministry of Foreign Affairs of the Islamic Republic of Iran. Archive. 1917; 28-53/36, 28-53/15,25,41,44, 28-53/46, 2853/48, 28-53/64-65.

29. Ministry of Foreign Affairs of the Islamic Republic of Iran. Archive. 1908; 22-01/73.

30. Documents and Press Archive of Astan quds Razavi; 1919; 63443/15-16.

31. Ra'd (newspaper). 1919;11(10): 2 .

32. Ra'd (newspaper). 1920;11(57): 2

33. Azizi MH, Raees Jalali GhA, Azizi F. A History of the 1918
Spanish Influenza Pandemic and its Impact on Iran. Arch Iran Med. 2010;13(3):262-5.

34. Floor WM. Studies in the History of Medicine in Iran. Trans. (in Farsi) by Nabipour I, Vahdat K, Nabipour I. Bushehr: Bushehr University of Medical Sciences; 2018: 221-228.

35. Arfa R. Prince Arfa's Memories. Trans. and edit. (in Farsi) by Dehbashi A. Tehran: Sokhan Publication; 1999:351.

36. Amin al-Zarb. Khorasan Dar Asnad Amin al-Zarb. Edit. by Afshar E, Pedram N, Mahdavi M (in Farsi). Tehran: Pooya Publication; 2011:302.

37. Ministry of Foreign Affairs of the Islamic Republic of Iran. Archive. 1901; 19-26/9, 19-26/14.

38. Malk al-Movarkhin A. Merat al-Vaghayye Mozaffari. 2nd ed. Edited by Navayi A. (in Farsi). Tehran: Written Heritage Research Institute 2007:901-902.

39. Ra'd (newspaper). 1920;11(89): 2.

40. Floor WM. Public health in Qajar Iran. Farsi translation by Nabipour Ir. (in Farsi). Bushehr: Bushehr University of Medical Sciences; 2007.

41. Hosseinzadeh-suresjani S. History of the astan - e quds daros safa (the Hospital) from the safavid to the end of Qajar period. Mashhad: Islamic Azad University; 2016:43. 